\title{
Public Relations as Da'wah Communication Strategies In Economic Empowerment of Islamic Communities
}

\author{
Oriza Agustin ${ }^{1}$, Khomsahrial Romli ${ }^{2}$, Fitri Yanti $^{3}$, Jasmadi $^{4}$, Indah Eftanastarini ${ }^{5}$, Leny \\ Setiyana $^{6}$ \\ \{ orizaagustin2017@gmail.com¹, khomsahrial@ radenintan.ac.id ${ }^{2}$, fitriyanti@ radenintan.ac.id ${ }^{3}$, \\ Jasmadi@radenintan.ac.id ${ }^{4}$, nastajalah@gmail.com ${ }^{5}$, Lenysetiyana@gmail.com ${ }^{6}$ \} \\ ${ }^{1}$ IAIN Metro, Jalan Ki Hajar Dewantara 15A Iringmulyo Metro Timur Kota Metro 34111, \\ Indonesia \\ 2,3,4,5 UIN Raden Intan Lampung, Jalan Letkol H. Endro Sutimin Sukarame Bandar Lampung \\ 35131, Indonesia \\ ${ }^{6}$ IAIN Metro, Jalan Ki Hajar Dewantara 15A Iringmulyo Metro Timur Kota Metro, Indonesia
}

\begin{abstract}
The purpose of this study is to find out Da'wah communication strategy in the economic empowerment of the Islamic community by using the theory of Public Relations in Amil Zakat DT Peduli Kota Metro. The goal is to achieve economic empowerment program target through Zakat, Infaq, Sedekah by the addition of new Donors / Muzakki. The research method used qualitative descriptive approach by actively involved in the economic empowerment program and interviews 30 informants from DT Peduli Metro management, government, Muzakki, Mustahik, Stakeholders and Corporate. The result is increasing of new Donors / Muzzaki by achievement of eight economic empowerment indicator through the implementation of the Public Relations strategy, namely Communal Space provided voluntarily by each Volunteers / Donors who become public consultant in attracting new Donors as volunteers in bringing up ideas and innovations maximizing DT Peduli's economic empowerment program.
\end{abstract}

Keywords: Public Relations, Da'wah Communication Strategy, Economic Empowerment

\section{Introduction}

In the era of information technology, various forms of communication media have been able to facilitate humans in interacting with their social and environment.[1] In relation to the process of da'wah as a form of development of Islamic societies, effective strategies are needed to be applied as a medium of communication. [2] One form of communication media is to use the theory of Public Relations which is a means to bridge humans to establish communication. Public relations will be a da'wah communication strategy that acts as a medium for delivering news, consultants, media publications, innovator strategies which then become a means that is able to influence people's awareness space so they have the same perspective in seeing things.[3] Media communication through public relations is able to bridge between outgoing internal management and stakeholders. The form of communication media from public relations is divided into digital and non digital communication media. Digital media can also be a da'wah communication strategy. Media has been carried out by DT Peduli in the form of online publications using social media. [4] By using social media, 
material is distributed in the form of solicitation and social movements to the community in accordance with the designed of target program. The form of material published to the public contains da'wah material using Tilawah strategy (reciting the verses of Allah SWT.), The Tazkiyah Strategy (purifying the soul), the Ta'lim strategy (teaching the Qur'an and AlHikmah). [5] This research was focused on Ta'lim Strategy which is asking partners to help deliver information about da'wah mission then establish public perceptions in making an active contribution in the implementation of the DT Peduli program. The program is an economic empowerment program for the community. Basically there are four main pillars of the DT Care program such as Education, Health, Da'wah, Economic. Among the four pillars, the economy is the most important pillar considering that DT Peduli is an Amil Zakat institution that manages Zakat, Infaq and Alms funds as the source of the entire four pillar program.[6] When the economy is able to sustain the other three pillars, DT Peduli program will be very beneficial for the community in implementing a real program. In its implementation, economic empowerment is carried out through the communication strategy. This strategy is more in the cognitive realm (thought) whose transformation passes through the sense of hearing $(a l$-sam $)$ and the sense of sight (al-abshar) and added to a healthy mind (al-af'idah). [7] Because every communication strategy must have a strategic plan that serves as a guide in the execution of publications and bridges all management and stakeholders both internal and external. Public relation is a da'wah communication strategy that plays an important role in the existence of an institution including DT Peduli.

In connection with the existence of an institution, in expressing a message from the program, a good communication is needed. It should be easily understood by the public and could be said to be effective if it is successful in achieving its goals and able to produce an attitude change in the communicant. [8]Etymologically the word effective is often interpreted to achieve the desired results and fun (having a pleasing effect). One of the problems in today's society, the economy, is an important concern by the National Amil Zakat Institute (Laznas), Dompet Peduli Ummat (DPU) Daarut Tauhid, which has now changed into DT Peduli.

In its implementation, LAZNAS receives the mandate of zakat, infaq, alms (ZIS) funds from Donors / Muzakki (zakat givers), should distribute to Mustahik (zakat recipients) in the form of programs or empowerment.[6] This means that the available funds are not only distributed in the form of charity. DT Peduli provides a long-term program and can be rolled out for other Mustahik. For example, we are rolling out an Independent Livestock Village empowerment program. Communities in the villages and surrounding Metro City areas, which incidentally Mustahik, were given assistance. But the aid was not in the form of money, but rather business capital in the form of livestock. After being given capital of livestock, the Mustahik are not left alone. They are given regular training, meetings and mentoring. In addition, livestock counselors and veterinarians also provide good management material for livestock. On the other hand, this program can be sustainable because DT Peduli has a Qurban program every year. So the sheep are distributed to the Mustahik when the sacrificial season, is distributed by DT Peduli. [9] So, this program is an ongoing program. As long as they are indeed still worthy of it. DT Peduli also provides limits. When observed from an economic standpoint, they have become better, they become Muzakki or Donors. We hope that the pattern of empowerment towards a society with a better economic level can be realized. In essence, not all poor people are poor in skills. DT Peduli directs to practice their skills. So that the poor do not constantly depend on the Zakat Fund.[10]

The program of empowerment is quite difficult. This program is different with the charity program which finished after providing the need. The empowerment program takes time. It takes long process. It can spend several months to years. This program will turn those who are powerless to be independent and then able to be independent from the economic side. The 
role of Public Relations is important in this long process. [3] Seeing the activities that have been carried out by DT Peduli Metro City in functioning zakat and alms as well as its role as one of the strategies in the welfare of the community, it is necessary to study scientifically how the role of Public Relations as Da'wah Communication Strategies in DT Peduli Metro City, how to implement Public Relations as Da'wah Communication Strategy in Economic Empowerment of Islamic Communities and its implications for increasing Donors / Muzakki, and what are the inhibiting factors of Public Relations as Da'wah communication strategies in Economic Empowerment of Islamic Communities in Metro City.[6]

Several problems found regarding the implementation the strategy da'wah program information and the implementation in the community. The success of the da'wah program effectively is largely determined by the communication strategy.If there is no good and effective communication strategy, it will have a negative effect. Communication strategy is a way to regulate the implementation of the communication process from planning, implementating, and evaluating in achieving the goal. Communication strategies must be able to demonstrate how operation should be tactically carried out.The approach can be different depending on the situation and condition.[11] The problems of DT Cares for Metro City were, DT Cares for Metro City was a new institution. The trust was low in manages and raises funds from the community. It is the main problem for DT Peduli in developing missionary mission in this case the economic empowerment of the Islamic community, especially in Metro City. Secondly, the lack of information to the public that DT Peduli was a trusted institution and had contributed significantly in the distribution of Zakat, infaq and alms where this institution is under the auspices of Daa'rut monotheism which is closely with the big name KH. Abdullah Gymnastiar or AA 'Gym. Third, the lack of partnership or community networks in the socialization, implementation, development and supervision of programs implemented by DT Peduli Metro City in communicating the program.[12]

Strategy is basically an art and science that uses and develops strengths (Ideology, Politics, Economy, Social Culture and Defense and Security) to achieve goals. The public relations communication strategy is carried out in a plan which includes ways, techniques and functional relations of the communication process to an activity to achieve a goal. [13] By implementing this strategy, it can provide support and aspirations that can be channeled or even vice versa. Based on those phenomenons, this study was important to be executed in revealing the role of Public Relations Institution of Amil Zakat DT Peduli Metro City in community empowerment and its implications for improving the people's economy. The researchers offered a concept of communication strategy DT Institution of Metro City in overcoming these problems through the Communal Space. It is a gathering place for various NGOs / community organizations and NGOs in building social interaction, online and offline program socialization. [14] It was expected that it became a strategy and answer for the entire community to be actively involved in the implementation of the concept. People are able to embark on it and state various opinions or program missions in achieving common goals. Communal space is one of the implementation of Public Relations that is in direct contact with various levels of society.[15] In accordance with Komunikasi Organisasi adalah pengiriman dan penerimaan berbagai pesan di dalam kelompok formal maupun informal dari suatu organisasi[16]

\section{Research Method}

This research used qualitative. It observed the DT Peduli Metro City preaching communication strategy towards improving the community's economy through the community empowerment program at DT Peduli Metro City. [17] The approach used descriptive qualitative. It was considered to observe understanding and good thinking from the 
management of the Amil Zakat Institute of DT Peduli Metro City. The target of research was the muzzaki and Mustahik. The research location was the Amil Zakat DT Peduli Institute in Metro City office.[18] This was one of the productive and active Amil Zakat institutions which directly benefited by the community and has a brand image under the care of A'a Gym. Based on preliminary observational data, DT Peduli Metro City was a well-known institution but its presence still has some shortcomings, especially in its public relations. The main data sources were words and actions. The rest was additional data such as documents and others. Informants are people who are chosen according to the interests of the problem and research objectives.[17] The selection of informants in this study was carried out by using snowball sampling. The key information in this study was the management of DT Peduli Metro City, Muzzaki, Donors and the Community.[18]

\section{Findings And Discussio}

\subsection{Findings}

Based on data obtained from https://data.metrokota.go.id, the number of moslem communities in Metro City in the year 2017 until now is 148,060 people. The data could be an opportunity is due to the analysis that the number of Muslims as much as 148,060 is expected to be a Muzakki candidate who will later distribute Zakat, Infaq, Alms (ZIS) to DT Peduli Metro City. [19] Apart from the various choices where the Donors will later distribute the funds. At least the expectation will be a source of funds that will later be maximized in its management in addition to charity but is empowered as a fund for the welfare of the community in the form of various programs. But in the opportunity there are definitely many challenges, among them there are still many among the people who believe they are more confident to convey directly and feel comfortable and faster / more practical when giving ZIS directly to their Mustahik. This is not prohibited considering that so many recipients who deserve to get help come from the family or closest people and even neighborhood neighbors who concretely need a helping hand without the need for Amil Zakat institutions. The reason for channeling such as this is not prohibited but strategically lacks a significant impact on poverty alleviation because generally it is direct giving, where funds are direct.[6]

\subsubsection{Identify Communication Goals}

In recognizing the communication target, DT Peduli Metro City used a work program by gathering a large audience which will provoke public curiosity about the existence of various programs and offer to the public in order to get a positive response to the continued participation of the community / Corporate. Various stakeholders and the local government should pay attention to the Da'wah program or charity which has a social movement with the mission of economic empowerment for the Ummah as its goal. The concrete form of this program was carried out by holding Tabligh Akbar, Blessing Friday, Alms and Meat for Orphans, Independent Livestock, and many other empowerment programs that have been felt by the community. DT Peduli Metro City can interact directly with the communicant's target through this program.

\subsubsection{Selection of Communication Media}

In maximizing the publication program which was related to Islamic Da'wah, in this case was Zakat, Infaq and Alms (ZIS) for the economic welfare of the people in the empowerment program, DT Peduli Metro City had a Religious and Social mission as well. 
The selection of appropriate, fast, effective and efficient communication media was very important for the continuous delivery of concrete reporting program information containing documentation and evidence to Muzakki / Donors that their donations have been delivered to people in various programs. Reporting on the results of audits of public accountants is delivered in the form of a report on the last page in DT Magazine, Swadaya. This magazine was informative periodical containing all information on the empowerment of DT Peduli throughout Indonesia and various information both studies from various religious leaders, scholarship information, publications on corporate promotion, Media Partners, Sponsorship and Stakeholders, Pesantren Da'arut Tauhid, reporting donations, Da'rut Tauhid's business products, Radio News Publications, DT-owned business entities such as Tour and Travel as well as the concrete structural ranks clearly and concretely to the public, and many others. All DT programs that contain the four pillars of the empowerment of Islamic societies were reform and develop in the fields of Economy, Health, Da'wah, and Education. Even though all the program remains missionary in the end.

\subsubsection{Assesment of Message}

In conveying the message of $d a^{\prime} w a h$, all depend on the purpose of communication, whether the communicant is merely knowing or taking certain actions. In communication trying to avoid the pronunciation of words that contain connotative meaning. The objectives study of the da'wah communication message also determines what techniques must be taken by DT Peduli Metro City. The purpose of communication from DT Peduli Metro City was to increase the number of Muzakki, so that funds were collected to be rolled out in an economic empowerment program. The purpose of DT Peduli Metro City in increasing the number of Muzakki, then informative, persuasive, and educational techniques are needed. There were many prospective Muzakki who did not understand about the obligation of ZIS. Not only providing information and education, but DT Peduli Metro City also tried to convince prospective Muzakki. Persuasive techniques were needed. Prospective Muzakki were invited to distribute ZIS to DT Peduli Metro City.

\subsubsection{The role of communicator in communication}

In delivering the $d a^{\prime} w a h$ content, it must be repeated and the publications will be rolled back periodically without stopping. It takes patience when repeating continuously. It would be stored accidentally in the memory of the public / Muzakki candidates and Donors. [3]

The way the preaching approach will be able to cling in the form of emotional closeness between DT Peduli Metro City as an actor as well as a communicator, with the good public that was old Muzakki, prospective Muzakki and Mustahik. [20] This role was important by DT Peduli Metro Public Relations in implementing the Da'wah communication strategy to empower the economy of the community for the community through Zakat, Infaq, Alms.

The success of a communication strategy cannot be separated from the role of a communicator. This role is carried out by DT Peduli Metro City by implementing strategies such as convincing prospective Muzakki by bringing in communicators [21] (in this case Public Figure or National and International Figures) who are influential in conveying messages because they are considered to have their own credibility and attractiveness (Image). A communicator which success in communicating, will be able to change the attitudes, opinions and behavior of the communicant through the mechanism of attraction. Next is how a trust becomes the spearhead of the Public Relations strategy in empowering the community when the communicant's trust in the communicator has a strong influence on the running of the DT Peduli Metro City program.[13] This can be seen from the social impact when a social 
movement on ZIS is publicly exposed, then at that time the communicant will see who landed this invitation, and what form the invitation will be. When the speaker is a communicator who has a positive image, the message conveyed will get a positive response. This effect the amount of donations both from Corporate and Donors and even the Government.[22]

Many factors are related to the profession, expertise and seniority of people. In its implementation, DT Peduli Metro City usually presents a communicator from expert staff in the government or the Sharia Board, the Supervisory Board, and the Management Board. The level of senior citizenship affects the community more than the implementing agency itself. The image branding of a DT leader will determine public confidence in it. For example, when a public figure has a business or product branding, it is faster to reach the community than ordinary people. This branding message will help a communicator in delivering the program and the da'wah content. Therefore leaders who already have this image will find it easier to gain public trust and be effective in their socialization without so much strategy and funding. DT Peduli Centre benefits from A'Aa Gym figure who has sold and benefited the brand from Daarut Tauhid itself. However, DT Peduli Metro City is pioneering towards the branding effect of a public figure like this even though there are still many problems.

\subsection{Discussion}

According Steward L. Tubbs and Sylvia Moss in Ruliana [2014: 31], communication style is a specialized interpersonal behavior device that is used in a particular situation. [23] DT Peduli Metro City in terms of organizational communication is more concerned with openness between employees. When openness is more important, ideas and opinions can be expressed without any limitation. It can be concluded that DT Peduli Metro City used the twoway communication style (the equalitarian style). [12] This communication style facilitates communication actions within the organization, because this style is effective in maintaining cooperation and empathy between employees.[6] Da'wah communication strategy is a combination of communication planning and management to achieve a goal. Another opinion, communication strategy is a mindset in planning an activity to change the nature, attitude of public opinion (communicant, audience, or mad'u) on a broad basis through the delivery of ideas.[24]

The preaching communication strategy used by DT Peduli Metro City was first to recognize the target of communication (Mad'u). [25] The approach was recognizing the target of preaching communication from DT Peduli Metro City to those who have not and who have been recognized in all levels society of Metro City.[10] DT Peduli Metro City also maximized efforts to increase the number of Muzakki from non-educated citizens. For example, DT Peduli could enter remote areas, hills, even inland on remote islands where the number of Moslems was rare to find but still got attention to be helped. Seeing this Mustahik target, DT peduli moved through local traditional leaders to help socialize to Mustahik candidates from more capable families. [6] Of course publications program cannot be used with social media publication strategies and flyers or magazines. [4] DT peduli must be directly involved with life as a strong dedication in carrying out its mission and social mission. Many people in traditional markets are heterogeneous and very diverse. In the market, there are also many generous people who targeted as Muzakki candidates, but sometimes the implementation is less than the maximum considering the approach to this community tends to be more complicated both in terms of energy and cost when deployed directly.[10] So the DT strategy used public which is to put up so many banners on strategic trajectories which is easily caught by the public eye. If you rent a big billboard in the middle of the city, it will take up a big budget so DT Peduli will consider installing a place that is free of charge for example 
traffic intersections. Besides intersection and traffic light, DT Peduli also jump right into the streets where so many street children and punk kids are. Although DT Cares has never offered a program directly to them, it turns out they have high social sensitivity and a strong sense of humanity. So when they are invited by volunteers to contribute, they helped to become donors by helping to raise funds on the streets. Their donation is not material or money, but rather the security and support. There is also an informant from the donor who tells that he does not able to make a donation, so he helped by actively publish and share every news update from DT Peduli without stopping. He created a community from the environment and his friendship to be actively involved in helping DT Peduli publications. Of course the effect of this infectious squash strategy was very effective for mapping out DT Peduli's missionary communication. Then there was also approaching people who have great power or influence in mobilizing the masses, for example with the advice of school children, then DT Peduli approaches through the Rohis network throughout Metro City. The approach can also be done through the teacher and then transmitted to the whole teacher. However, this cannot be used as a reference for DT Peduli donors who are consistent in donating. The strategy of recognizing the intended target is to make a contract offer with the school in the form scholarship offers for poor students, dormitory for 5 poor students, entrepreneurial assistance for students, MMQ (Majlis Manajemen Qolbu) for teachers and students, Alms-Easier Services for teachers and students with the application and Direct Pick, Go-Pay application. Da'wah communication strategy is a combination of communication planning and management to achieve a goal.[26] Another opinion says communication strategy is a mindset in planning an activity to change the nature, attitude of public opinion (communicant, audience, or mad'u) on a broad basis through the delivery of ideas.

\section{The Concept of Communal Space as a Public Relations Solution As a Communication Strategy for Da'wah Economic Empowerment of Islamic Communities Da'arut Tauhid Care for Metro City}

After observing directly the physical data of infrastructure facilities and obstacles in the field through interviews with informants, the researchers analyzed that public space is needed or commonly called communal space for its inhabitants and for the wider community.[14] From the interview results, it is known that the reason for the site / land is limited, even though the public space is very useful for gathering and interacting to contribute ideas to be actively involved in the development of programs with fellow management, Muzakki, Mustahik donors and the wider community.[15] This is the background of researchers to develop the concept of communal / public space from the willingness of each volunteer or donor, so that moving in the form of team collaboration is no longer focused on management which is limited in number. Focusing on this concept, researchers gave the movement a designation as "One Donors One Space". "Public Space" in the availability of each volunteer to become a part of DT Peduli where all activities and community gatherings in activities contribute to the idea of economic empowerment.

Control in the use of public space is related to tolerance of the interests of others who also use the public space. Public space is characterized by three things namely responsive, democratic and meaningful [Putnam, 1993] [28]: 1. Responsive in the sense of public space must be used for various activities and broad interests. 2. Democratic means that public space should be able to be used by the general public from various social, economic and cultural backgrounds and accessibility to various physical conditions of humans. 3. Meaningful which 
means that public space must have a link between humans, space, the wider world and social context. Public space is a public place or spaces that can be used for mutual interests, but the time of use is not necessarily used at the same time. So what is meant by shared use is in the context of "space". [29] "Public space" recommendations such as public terraces, gazebos, or lesions are comfortable places to use, because from the results of data obtained from the morning management of DT Peduli Metro City. as well as solidarity within the community, to introduce new life values in solving life's problems including including landing ideas for economic empowerment from and for Islamic society as a top priority. The informants explicitly stated that they were confused by the continuity of the friendship process with DT Peduli. They were very enthusiast in DT Peduli's activities. They wanted to participate, but there was a lack of sustainability response regarding briefing, studies or meet ups to discuss the programs they had chosen previously. Likewise with new donors or Muzakki, the brand is even more confused considering the lack of DT Peduli's advertising promotional material that is present in open spaces such as in large billboars in shopping centers and offices. While some of the old donors had rarely been followed up by management, they forgot to contribute actively, especially with the new Muzakki or Donator candidates. They were more unaware of the existence of DT Peduli. The concept of communal space will be very effective to bridge various parties both internal and external with a budget that is not relatively large. The informants explicitly stated that they were emotionally attached to Management of DT Peduli. They were comfortable and salute the social movements that the community had benefited from. The statement of the informants in the elaboration of the concept that the researchers proposed was that they welcomed with delight the concept and wanted to help by discussing it with DT Peduli. Various groups can be present without differences in status and position because the mission is to preach and be efficient in the economic field for others. The informants explicitly stated that the benefits could be felt through rupiah collected from the DT Peduli program which was not charity or other. There were cross subsidies with profit sharing with DT Peduli with certain calculations, which will later be used to help empower other Mustahik. In addition to profits in the form of money, the fabric of brotherhood that is fostered in the form of togetherness is an advantage in the non-material context. Profits derived from operating results are not only reflected through the value of the rupiah, but are also born through fraternal relationships that are always maintained. The bond of brotherhood between fellow Mustahik and DT Peduli Metro City volunteers that are interwoven more closely is not based on worldly reasons alone but an intention to worship to help the people.

\section{Conclusions}

The results of the analysis of values in the indexicality and reflexivity rules showed that the spirit of religious values, togetherness, cultural values, social values, local wisdom and economic values were internalized in the buying, selling and in the process of obtaining profits in the DT Peduli Metro City community. Metro City people who are cultured and intellect give spirit to the identity of the DT Peduli community in carrying out sustainability in the implementation of the program. On the other hand, it defines operational values in the form of values of honesty, love, justice and trust. Determination of selling prices not only serves as a means to give birth to economic value, but also as a field of acquisition of religious values in the form of reward, honesty, love, justice and trust. These values grew and developed within a framework of living that is "impervious to heat and not weathered by rain". As an example of local wisdom owned by the Minang Kabau community, "Ota Lapau" where various ideas and criticisms of social phenomena are born and landed. The sign of the 
economic benefit in the view of the DT Peduli community was formed from the understanding of religion. The da'wah of Islam carried on the 4th pillar of Islam, consisting of material values and non-material manifestations. The addition of capital in non-material values is expressed through honesty, trust, justice and love. Meanwhile, profits generated in the form of material or money. Thus it could be said that these two values showed the struggle of the public relations of DT Peduli Metro City in undergoing communication strategies for social movements (economic empowerment) and for the mission of Islamic da'wah.

\section{Reference}

[1] O. U. Effendy, Ilmu, Teori dan Filsafat Komunikasi. 2003.

[2] E. AS, "Pengembangan Masyarakat Islam dalam Sistem Dakwah," Jurnal Ilmu Dakwah. 2011.

[3] T. E. Ardhoyo, "Peran dan Strategi Humas (Public Relations) dalam Mempromosikan Produk Perusahaan," J. Ilm. WIDYA, 2013.

[4] A. Zaini, "DAKWAH MELALUI INTERNET," Komun. penyiaran Islam, 2013.

[5] S. Suriati, "MAJEUS TA'LIM: Strategi Dakwah Dalam Mempererat Ukhuwah Islamiyah," Al-Mishbah| J. Ilmu Dakwah dan Komun., 2017.

[6] H. Herman, "Strategi Komunikasi Pengelolaan Zakat, Infak, dan Sedekah (ZIS) Melalui Media Sosial," Commun. J. Ilmu Komun., 2019.

[7] P. Pramita, "RETORIKA DAKWAH YUSUF MANSUR DAN PEMANFAATANNYA SEBAGAI BAHAN AJAR BERBICARA DALAM BENTUK CD INTERAKTIF UNTUK SISWA SMA,” Ranah J. Kaji. Bhs., 2015.

[8] R. Ruslan, "Manajemen Public Relations \& Media Komunikasi.," in Manajemen Public Relations \& Media Komunikasi, 2014.

[9] F. H. Nugraha, A. W. Riana, and M. Irfan, "PARTISIPASI MASYARAKAT DALAM PROGRAM DESA TERNAK MANDIRI (DTM) DOMPET PEDULI UMAT DARUUT TAUHIID (DPUDT) DI NESA NEGLASARI KECAMATAN MAJALAYA KABUPATEN BANDUNG," Share Soc. Work J., 2015.

[10] R. A. Kasri and N. I. S. Putri, "Fundraising Strategies to Optimize Zakat Potential in Indonesia: An Exploratory Qualitative Study," Al-Iqtishad J. Ilmu Ekon. Syariah, 2018.

[11] P. E. Simanullang, "PUBLIC RELATIONS SEBAGAI STRATEGI KOMUNIKASI PEMASARAN," NIAGAWAN, 2019.

[12] J. Elmborg, "STRATEGI BRANDING IMAGE," Transform. Inf. Lit. Programs Intersecting Front. Self, Libr. Cult. Campus Community, 2012.

[13] S. A. Artis, "Strategi Komunikasi Public Relation," Sos. Budaya, 2011.

[14] S. Winarni, G. W. Pangarsa, A. Antariksa, and L. D. Wulandari, "COMMUNAL SPACE IN ISLAMIC ACTIVITY OF DUKUH KRAJAN, DESA KROMENGAN,KABUPATEN MALANG,” J. Islam. Archit., 2014.

[15] D. Kromengan and K. Malang, "Ruang Komunal pada Aktivitas Ekonomi di Dukuh," ARSKON, J. Arsit. dan Konstr., 2013.

[16] T. Gutama, "PERAN KOMUNIKASI DALAM ORGANISASI," J. Sosiol., 2010.

[17] I. Gunawan, Metode Penelitian Kualitatif: Teori dan Praktik. 2014.

[18] A. Suharsimi, Prosedur Penelitian : Suatu Pendekatan Praktik (Edisi Revisi). 2013.

[19] "https://data.metrokota.go.id." .

[20] S. Bungo, "PENDEKATAN DAKWAH KULTURAL DALAM MASYARAKAT 
PLURAL," J. Dakwah Tabligh, 2014.

[21] S. Ag, "STRATEGI KOMUNIKASI PUBLIC RELATIONS Oleh: Artis, S.Ag Abstraksi," Strateg. Komun. Public Relat., 2011.

[22] R. Juwita, "PRAKTIK PUBLIC RELATIONS DAN CORPORATE SOCIAL RESPONSIBILITY DALAM PERUBAHAN SOSIAL GLOBAL," Interak. J. Ilmu Komun., 2017.

[23] R. Poppy, "Komunikasi Organisasi:Teori dan studi Kasus," in Jakarta: Rajawali pers, 2014.

[24] Hanifah Gunawan, Karim Suryadi, and Elly Malihah, "Analisis Perubahan Sosial Budaya Masyarakat Desa Cihideung sebagai Desa Wisata," Sosietas, 2015.

[25] U. Marfu'ah, "STRATEGI KOMUNIKASI DAKWAH BERBASIS MULTIKULTURAL," Islam. Commun. J., 2018.

[26] Azwar, "Pengaruh Gaya Kepemimpinan, Komunikasi, Dan Disiplin Kerja Terhadap Kinerja Karyawan,” J. Ilmu dan Ris. Manaj., 2015.

[27] D. P. Lestari, “Analisis Strategi Internet Marketing Butik Online Di Surabaya Melalui Instagram," Commonline Dep. Komun., 2015.

[28] P. P. Egam, "Ruang Publik," EKOTON, 2014.

[29] Y. Pratiwi, "TRANSFORMASI FUNGSI RUANG TERBUKA PUBLIK DI PERKOTAAN STUDI KASUS:TAMAN PEDESTRIAN KECAMATAN TENGGARONG, KABUPATEN KUTAI KARTANEGARA, KALIMANTAN TIMUR," NALARs, 2016. 